\title{
Interaction between HIV and its host: role for viral and cellular sncRNA
}

\author{
Monsef Benkirane \\ From Frontiers of Retrovirology 2011 \\ Amsterdam, The Netherlands. 3-5 October 2011
}

The primate lentivirus auxiliary protein Vpx counteracts an unknown restriction factor that renders human dendritic and myeloid cells largely refractory to HIV-1 infection. We recently identified Samhd1 as this restriction factor. Samhd1 is a protein involved in AicardiGoutière Syndrome (AGS), a genetic encephalopathy with symptoms mimicking congenital viral infection that has been proposed to act as a negative regulator of the interferon-stimulated DNA response. We show that Vpx induces proteasomal degradation of Samhd1. Silencing of Samhd1 in non-permissive cell lines alleviates HIV-1 restriction and is associated with a significant accumulation of viral DNA in infected cells. Concurrently, overexpression of Samhd1 in sensitive cells inhibits HIV-1 infection. The putative phosphohydrolase activity of Samhd1 is likely required for HIV-1 restriction. Vpxmediated relief of restriction is abolished in Samhd1 negative cells. Finally, silencing of Samhd1 dramatically increases susceptibility of MDDCs to infection. Altogether, these results demonstrate that Samhd1 is an anti-retroviral protein expressed in cells of the myeloid lineage and inhibiting an early step of the viral life cycle.

Submit your next manuscript to BioMed Central and take full advantage of:

- Convenient online submission

- Thorough peer review

- No space constraints or color figure charges

- Immediate publication on acceptance

- Inclusion in PubMed, CAS, Scopus and Google Scholar

- Research which is freely available for redistribution 